\title{
Teko Haxy: autoetnografia e o documentário dispositivo na terra imperfeita
}

\author{
Carlos Pérez Reyna ${ }^{1}$ \\ Mariana Stolf Friggi ${ }^{2}$
}

Resumo

Este artigo tem como objetivo discutir os aspectos estilísticos e subjetivos dos conceitos de autoetnografia e documentário dispositivo em primeira pessoa, construídos pelo encontro entre Patrícia Ferreiro Pará Yxapy e Sophia Ferreira Pinheiro, cujo resultado é o documentário experimental Teko Haxy-Ser Imperfeita (2016). O filme é particularmente instigante para saber, como essas vozes estão construídas, do que falam essas vozes e, certamente, quais são as questões estéticas e subjetivas advindas desse documentário que deriva do ato de filmar a outra e a si mesmas. Para elaborar essa análise fílmica, utilizamos os princípios metodológicos da antropologia do cinema, notadamente, o conceito de etnografia fílmica e, os princípios metodológicos de mise en scène e auto-mise en scène oriundas da antropologia fílmica.

Palavras-chave: autoetnografia; documentário dispositivo; etnografia fílmica; antropologia fílmica

Abstract

This article is intended to discuss the stylistic and subjective aspects of the concepts of autoetnography and first person device documentary, built by the meeting between Patrícia Ferreiro Pará Yxapy and Sophia Ferreira Pinheiro, whose result is the experimental documentary Teko Haxy- Ser Imperfeita (2016). The film is particularly stimulating to know, how these voices are built? What are these voices talking about? And, certainly, what are the aesthetic and subjective questions arising from this documentary that derives from the act of filming the other and themselves? To elaborate this film analysis, we use the methodological principles of film anthropology, notably, the concept of film ethnography and, the methodological principles of mise en scène and auto-mise en scène derived from film anthropology.

Keywords: autoetnografia; documentary device; filmic ethnography; anthropology filmic

\section{Introdução}

Desde seu primeiro encontro, o cinema e a antropologia têm um logo percurso de afinidades e interesses. Ambos se desenvolveram no final do século XIX nas viagens aos horizontes mais distantes, em um tempo que a América e Europa buscavam mercados propícios às exigências de seu expansionismo econômico e colonialista. Desde então, o diálogo entre produtores de imagens 
e antropólogos (fotógrafos e cineastas) é estimulado pela inserção de novas tecnologias de dispositivo, pelo surgimento de novas tendências, e pelas problematizações e debates de novas categorias e experimentações. Hoje, no diálogo entre o documentário ${ }^{3}$ e a antropologia, veremos um território fértil a novas narrativas, novas concepções, e novas propostas estéticas, que coloca, a ambos territórios, uma alternativa de ampliação de fronteiras.

Uma dessas preocupações passa necessariamente sobre a experiência do conhecimento do Outro (alteridade). Isto é, qual horizonte experimental de expectativas tem o documentário e antropologia no que diz respeito à experiência da alteridade, definida aqui como a experiência do "encontro"? Também chamado por Laplantine como "estranhamento", é provocada pelo encontro das culturas que são para nós mais distantes, cujo encontro vai levar a uma modificação do olhar que se tinha sobre si mesmo. (2003). Segundo o autor:

\footnotetext{
“a elaboração da experiência da alteridade levanos a ver aquilo que nem teríamos conseguido imaginar, dada a nossa dificuldade em fixar nossa atenção no que nos é habitual, familiar, cotidiano e que consideramos "evidente". Aos poucos, notamos que o menor dos nossos comportamentos (gestos, mímicas, posturas, reações afetivas) não têm realmente nada de "natural". Começamos, então, a nos surpreender com aquilo que diz respeito a nós mesmos, a nos espiar. O conhecimento (antropológico) da nossa cultura passa inevitavelmente pelo conhecimento das outras culturas; e devemos especialmente reconhecer que somos uma cultura possível entre tantas outras, mas não a única”. (2003 p. 13)
}

Com efeito, presos a uma única cultura, somos não apenas cegos aos outros, mas míopes quando se trata da nossa.

É nesse sentido que este trabalho se orienta, de que "outra" maneira podemos construir e/ou representar esse Outro, cuja imagem sem reflexo cria a ilusão de uma sociedade sem espelho? $\mathrm{Ou}$ melhor ainda, de que maneira podemos criar narrativas em que esse Outro possa criar suas próprias narrativas, seu próprio espelho? Hoje, o documentário e a antropologia, nos oferecem uma via de acesso a essa experiência pessoal, em que o "eu" constrói e produz seus próprios sentidos. Um exemplo disso, é Teko Haxy - Ser Imperfeita (2016), um documentário experimental sobre o encontro de Sophia e Patrícia, uma mulher branca e uma indígena que o tempo todo exercitam o ato de filmar a outra e a si mesmas. Sophia Pinheiro é antropóloga, artista e cineasta, e Patrícia Ferreira é professora e uma das principais cineastas indígenas Guarani Mbya atuante no projeto "Vídeo nas Aldeias". Entre elas, discutem sobre as semelhanças e diferenças das dores e desafios de serem mulheres, cada uma inserida em uma cultura diferente. $\mathrm{O}$ filme é particularmente instigante para saber, como essas vozes estão construídas? De que falam essas vozes? E, certamente, quais são as questões estéticas e subjetivas advindas desse documentário que deriva do ato de filmar a outra e a si mesmas?

\section{O ponto de vista do "eu" no cinema documentário ou documentário em la pessoa}

Dentre os diversos conceitos desenvolvidos para qualificar, ou mesmo distinguir os documentários de outros tipos de produções fílmicas e/ou videográficas, está o conceito de voz. Carl Plantinga (1996) e Bill Nichols (1988) são dois pesquisadores que adotam esse conceito, pois, é através da voz, que os documentários representam aspectos deste mundo a partir de um ponto de vista ou perspectiva. Para efeitos de nossos propósitos utilizaremos as aproximações conceituais sobre a voz que Bill Nichols nos ensina. Segundo o autor, a voz está intimamente ligada à forma como o cineasta expressa uma perspectiva, como ele transmite, representa sua 
visão sobre questões, problemas e características do mundo histórico. Vejamos:

Por voz, refiro-me a algo mais restrito que o estilo: aquilo que, no texto, nos transmite o ponto de vista social, a maneira como ele nos fala ou como organiza o material que nos apresenta. Nesse sentido, "voz" não se restringe a um código ou característica, como o diálogo ou o comentário narrado. Voz talvez seja algo semelhante àquele padrão intangível, formado pela interação de todos os códigos de um filme, e se aplica a todos os tipos de documentário. (2007 p.50).

A voz (a fala) também está intrinsecamente relacionada ao estilo do filme e configura um elemento determinante na diferença entre ficção e documentário, e entre os próprios subgêneros documentários. No caso deste último, o estilo se refere à forma como o diretor busca traduzir sua visão sobre alguma questão do mundo histórico, e também, seu envolvimento com a temática, ou seja, a voz serve para tornar concreto o engajamento do cineasta com o mundo. Ele fala dos outros para nós? Apenas observa ou também interage com o Outro? Participa dessa relação, desse encontro com seu tema? Ou, de maneira inversa, a voz do cineasta é a mesma que nos diz, subjetivamente, seu ponto de vista sobre o mundo, criando um caminho de acesso íntimo ao político?

No sentido de organizar as diferentes abordagens $^{4}$ acima mencionadas, Bill Nichols identifica seis tipos de documentários: poético, expositivo, participativo, observativo, reflexivo e performático. Esses modos de representação documental estão ligados a um determinado período histórico da evolução do documentário, isso não quer dizer que devam ser levados de maneira literal, qual uma receita, visto que eles não são incólumes ou puros. Pelo contrário, cada tipologia pode mesclar características de outras. Não existe uma rigorosa diferenciação entre eles, embora além de exercer uma grande influência contemporaneamente, ela nos oferece substrato para um melhor entendimento de nossas análises fílmicas. Assim sendo, voltamos nossos interesses ao modo performático de expressar a compreensão do mundo por meio de dimensões subjetivas e afetivas, tal qual como acontece com o filme Teko Haxy.

Quais são as características do modo performático no documentário? Segundo Nichols "o documentário performático restaura uma sensação de magnitude no que é local, específico e concreto. Ele estimula o pessoal, de forma que faz dele nosso porto de entrada para o político". (2007, p.176)

Este tipo de documentário defende que o conhecimento não é algo abstrato, mas sim concreto e corporificado pelas experiências pessoais, como propugnado pela tradição da literatura autobiográfica. O documentário performático se dirige primeiramente a nós, emocional e expressivamente, ao invés de apontar o mundo factual que compartilhamos. É um modelo de documentário, pelas chamadas minorias, que não encontra, nos modos de representação vigentes, possibilidades de expressar-se completamente. Sua subjetividade é sempre a dos que se sentem sub-representados, ou mal-representados, como mulheres, minorias étnicas, gays e lésbicas. $\mathrm{O}$ modo combate os que propalam "Nós falamos sobre eles pra nós e se oferecem, em seu turno, para dizer Nós falamos sobre nós para vocês, ou melhor ainda Nós falamos sobre nós para nós mesmos." Esteticamente, adotam o uso livre de técnicas cinematográficas, como câmera subjetiva, slow motions, flash-backs, filtros coloridos, números musicais, congelamento de cenas e imagens desfocadas ou embaçadas, entre outras.

As abordagens do modo performático penetram no domínio do cinema experimental e de vanguarda, mas colocam menos ênfase na qualidade do filme (ou vídeo) do que na expressividade das representações que nos remetem ao mundo histórico. Todavia, o mundo

4 Para mergulhar esses diferentes modos de representação que funcionam como uma espécie de subgêneros convido ao leitor a leitura da obra do autor, Introdução ao documentário. Campinas: Papirus Editora, 2007. 
histórico torna-se excessivamente iluminado por tons evocativos e colorações expressivas que nos lembram constantemente de que o mundo é mais do que a soma das evidências que temos dele.

O documentário performático tem uma genealogia que vem dos anos 1970, quando se começou a falar de "cinema subjetivo", ou "cinema do eu", "mise en je", "cinema em primeira pessoa", "autobiografia" (Bellour 1997). A câmera, nesta modalidade de documentário, é colocada em uma espécie de última fronteira: o universo pessoal do cineasta. O "eu" tenta se inscrever na enunciação documentária.

A respeito da experiência do "eu" no documentário brasileiro, temos dois exemplos, entre outros, que exemplificam essa modalidade performática. Nos referimos a dois filmes contemporâneos: Passaporte Húngaro de Sandra Kogut (2002) e 33 de Kiko Goifman (2003). Em ambos filmes, a experiência do encontro ou a alteridade clássica do encontro é quebrada para dar passo ao específico, concreto e íntimo da experiência pessoal, logo subjetivo, dos cineastas. Há um transtorno visível da experiência dos realizadores - de seus corpos, de suas disposições psicológicas e de suas atitudes. Isto é, diferente da velha narrativa de objetividade/verdade, em ambos filmes, são minimizados em favor de representações do "eu", de trabalhos subjetivos, geralmente pessoais e autobiográficos. Os realizadores estabelecem um projeto, sabem seu ponto de partida, têm seus objetivos mais ou menos definidos, o percurso é construído e não sabem dos resultados.

\section{Inflexões do "eu" na narrativa do cinema documentário}

Contemporaneamente, existe uma série de inflexões, estéticas, discursos sociais e novas tecnologias que habilitam e explicam modulações e variações interessantes e decisivas quando pensamos na crescente produção documentária da subjetivação. Grosso modo podemos mencionar três: a) o "eu" realizador fala sobre si mesmo e, b) o "eu" realizador fala com o Outro e c) o "eu" realizador fala sobre o Outro".

A primeira, narrativas sobre si, onde filmes documentários podem construir uma subjetividade plural e dialógica. Como mencionamos nos filmes anteriormente, Passaporte Húngaro (2002) e 33 (2003), têm como fio condutor, um discurso autorreferente onde as trajetórias de uma vida, e a própria existência do sujeito histórico, ganham valor em múltiplas manifestações: diários íntimos, confissões, memórias, todas incluídas na narrativa autobiográfica. Nessa narrativa, o espaço autobiográfico é constituído por discursos complexos e paradoxais, não apenas dicotômicos, que têm como potencialidade a mobilização sensível e intelectual de seus receptores, interpelados por um sujeito que expõe seus próprios limites, seu espelho, e a impossibilidade de alcançar uma definição absoluta e verdadeira de si mesmo e do mundo.

A segunda, encontramos narrativas da experiência e de alteridade. Nestes documentários existe um constante feedback entre a experiência do cineasta e o Outro. Como resultado disso, observa-se o caráter relacional desse encontro, em que a experiência e a percepção do Outro, profundamente comovido, tem sua narrativa ressignificada que, por sua vez, é atravessada por um olhar fortemente subjetivado. No plano internacional temos dois filmes que ilustram esta modalidade: Les glaneurs et la glaneuse... deux ans après (Os catadores e eu) (Agnès Varda, 2002) e Sherman's March (Ross McElwee, 1987). Por último, a terceira, onde a primeira pessoa é só uma presença desapegada e levemente vinculada à história que narra. A presença do cineasta funciona como uma agente catalizador dos processos fílmicos, também chamado "a mosca na sopa”. É uma inflexão no cinema documentário, pela inserção de novos dispositivos tecnológicos mais leves, além do cineasta interagir com o Outro, permite deslocamentos subjetivos com

5 Nesta modulação se inscreve obras como Crónica de um verão (1960) de Jean Rouch e Edgard Morin e Le joli mai (1963) de Chris Marker. Em ambos filmes, a cenificação dos cineastas funciona como agente catalizador da ação. 
esse Outro. Nesta modalidade se inscrevem obras como Crónica de um verão (1960) de Jean Rouch e Edgard Morin e Le joli mai (1963) de Chris Marker.

Acreditamos que, ao igual que as modalidades do documentário, o subgênero em primeira pessoa, também permite mesclas entre elas. Uma delas trata-se da modalidade de documentário que deriva do ato de filmar a outra e a si mesmas: eu te filmo e você me filma, conversamos entre nós, nos filmando, como um jogo de espelhos. Um exemplo disso é nosso filme em questão, Teko Haxy. Este documentário será, mais adiante, motivo de nossa análise fílmica.

\section{O ponto de vista do "eu" no cinema antropológico}

Um dos motivos sobre os modos de aparecimento do cinema ao longo da história teve sua origem ligada à pesquisa antropológica. Desde esse então, o diálogo entre antropólogos e documentaristas é estimulado pelo surgimento de novas tendências, pela problematização e debates de novas categorias aos quais, em certa medida, redefinem a pesquisa etnográfica. Concomitante a isso, os avanços de novas tecnologias da imagem permitem, tanto ao filme quanto à fotografia, irem além da simples utilização das imagens animadas e fixas como instrumento de registro. Historicamente, a antropologia tem muitos pioneiros que utilizaram do filme como meio de documentar o que se entendia na época como sociedades pouco evoluídas. A realização desses documentários fez deles precursores da transformação dos métodos clássicos de pesquisa antropológica.

Hoje, os métodos e as escritas etnográficas associados à antropologia pós-moderna sugere à etnografia contemporânea que a apresentação dos resultados das pesquisas nos textos etnográficos devem responder à necessidade de incluir as vozes dos Outros (sujeitos sociais) em coautoria entre o etnografado e o etnógrafo. Nesse sentido, há a necessidade de trazer a nossa proposta, o debate realizado pelo antropólogo James Clifford em: Writing Culture: The Poetics and Politics of
Ethnography (1986) editada em coautoria do antropólogo George E. Marcus e, o ensaio Sobre a autoridade etnográfica na obra $A$ experiência etnográfica: antropologia e literatura no século XX (1998).

A primeira, sobre o manto da objetividade científica ou "realismo etnográfico", analisa criticamente as negociações da posição do etnógrafo na sociedade pesquisada e suas condições intersubjetivas de observação e interação. Isto é, James Clifford se refere às intrincadas relações entre a construção dos textos etnográficos e os processos de produção de conhecimentos sobre os Outros, tomando como base as propostas dialógicas e polifônicas bakhtinianas. A segunda, reforça ainda mais o rompimento com as autoridades monológicas das etnografias experiencial e interpretativa a dois outros modos de autoridade: o dialógico e o polifônico. Segundo Clifford, o modo de autoridade dialógico entende a etnografia como resultado de uma negociação construtiva envolvendo pelo menos dois ou, muitas vezes, mais sujeitos conscientes e politicamente significativos. Já o modo de autoridade polifônico, que rompe com as etnografias que pretendem conter uma única voz, geralmente a do etnógrafo, propõe a produção colaborativa do conhecimento etnográfico, dentre elas, citar informantes extensa e regularmente. Quer dizer, nas próprias palavras do autor: "um modelo discursivo de prática etnográfica traz para o centro da cena a intersubjetividade de toda fala (voz), juntamente com seu contexto performativo imediato" (1998 p.41 Grifo nosso)

Grosso modo, James Clifford ao romper o poder absoluto do etnógrafo baseado na sua observação pessoal com a representação do Outro, as múltiplas vozes presentes na etnografia, muita das vezes "escondidas", hoje, estão a ser descobertas e apresentadas. Isto é, ao inverso da etnografia tradicional, que falava sobre o Outro e pelo Outro, o etnógrafo passa a falar com o Outro. A produção de textos e discursos etnográficos é uma elaboração relacional resultado de um processo dialógico e/ou polifônico que busca ser uma alegoria do encontro entre subjetividades 
de duas culturas diferentes: os etnografados e o etnógrafo, entre o Outro e o pesquisador.

Dos diferentes territórios da antropologia, a antropologia visual foi aquela que, na alteridade, tentou criar entrelaçamentos na busca da representação do Outro. Vejamos; às experiências de produzir filmes etnográficos ${ }^{6} \operatorname{como~resultados}$ de pesquisas; registrar informações e observações através da imagem visual; realizar filmes a partir de pesquisas antropológicas; soma-se aquilo que, em antropologia contemporânea, chama de antropologia reversa ou simétrica (Castro 2012), onde o próprio nativo ou o Outro, até então sujeito dos filmes etnográficos, passa a ser autor de seus registros fílmicos.

$\mathrm{Na}$ prática, de uma experiência a outra - de Nannok (1922) de Robert Flaherty às experiências de Navajo Film Themselves (1966) de Sol Worth e John Adair, passando por Ateliers Varan (1981) fundada por Jean Rouch até Video nas Aldeias ${ }^{7}$ (1986) do Vincent Carelli -, em sua busca pela imagem do Outro, o cinema etnográfico passa por amplas transformações, fazendo atravessar a tradição do cinema e as teorizações e pesquisas no âmbito da antropologia. Entre essas transformações, revela-se o ponto de vista do nativo sobre sua própria imagem e sobre o olhar daquele que a realizou. Nesse sentido, nos parece colocar o Outro em condições de discorrer sobre seu mundo e o mundo do branco, através do cinema, tomado como uma prática de produção de conhecimento que coloca o branco e o indígena em pé de igualdade.

No que diz respeito a esse tipo de produção etnográfica no Brasil, gostaríamos de salientar a relevância dos filmes do projeto Vídeo nas
Aldeias (VNA), como lugar de um pensamento cinematográfico de onde surgem como nova proposta. Tomando como pano de fundo as ideias de Roy Wagner (2010) e de Eduardo Viveiros de Castro (2012), que reivindicam uma "antropologia nativa", podemos sugerir que os grupos ameríndios ou não, possam representar o seu mundo, e também o mundo de outrem. E que, ao fazê-lo, ressignifiquem os próprios processos de produção cinematográfica e de produção de imagens. Assim, as relações historicamente construídas pelo cinema são reconfiguradas, no interior de práticas tradicionais, em relações étnicas e Inter étnicas.

\section{Documentários autoetnográficos e suas fronteiras experimentais}

Assim, pelo exposto panoramicamente até aqui, vemos que o sujeito "eu" como produtor de conhecimentos, tanto na antropologia, quanto no cinema, é uma categoria cuja utilização não é recente. $\mathrm{Na}$ aproximação das experiências e reflexões entre o documentário e a antropologia e sua implícita alteração do papel do cineasta e do antropólogo perante as novas formas de construção de narrativas sobre a representação do Outro, fundamentamos aquilo que o documentário denomina de filmes de nãoficção em primeira pessoa (performático) e, as escritas sobre si na antropologia, de antropologia simétrica ou reversa.

Conceitualmente, no documentário, quando falamos o termo "filme em primeira pessoa" endereçamos fundamentalmente à modalidade de filmes que "falam" do ponto de vista articulado

6 Não é nossa intenção de entrar em terrenos históricos, para uma melhor compreensão do processo de formação do filme etnográfico, sugiro leituras dos seguintes textos de: (versão em francês) Emilie de Brigard. "Historique du film ethnographique”, in Claudine de France (Org) Pour une anthropologie visuelle, Paris (EHESS), 1979, pp. 21-51. (versão em inglés); Op. Cit., “The History of Ethnographic Film”, in Paul Hockings (Org.) Visual Anthropology, La Haye (Mouton), 1975, pp. 13-43; e Pierre Jordan. "Primeiros contatos, primeiros olhares", in Cadernos de Antropologia e Imagem, Rio de Janeiro, UERJ, 1995. pp. 11-22.

7 O Centro de Trabalho Indigenista (CTI) e, mais tarde, o projeto "Vídeo nas Aldeias", foi criado por Vincent Carelli em 1986. A proposta é revelar autores com subjetividade e não objetos de estudo da antropologia. Essa escolha se relaciona diretamente com o momento em que a antropologia se questiona a respeito da subjetividade de seus etnografados. O próprio Carelli menciona: "esse projeto tem por objetivo promover a apropriação e manipulação de sua imagem pelos próprios índios. Essa experiência, essencial para as comunidades que a vivenciam, representa também um campo de pesquisa revelador dos processos de construção de identidades, de transformação e transmissão de conhecimentos, de formas novas de autorrepresentação" (1995, p. 67). Ou como diria Catherine Russel (1999) suas próprias autoetnografias, contrária à etnografia praticada pelos antropólogos. 
do cineasta e que, notadamente, reconhece, entre outras coisas, sua posição subjetiva. São construções de narrativa própria do tipo autobiográficas e de construção de identidades (destruição, ameaça ou afirmação).

Do mesmo modo, na antropologia, quando se fala de associar estudos $\left(\right.$ método $^{8}$ ) com foco nas noções de sujeito social ou de subjetividade, mediante questões sobre a subjetividade e, onde, o Outro nativo assume o papel de etnógrafo enquanto produtor de conhecimento, é denominado de autoetnografia ${ }^{9}$. Como definir esse conceito dentro do cinema experimental e do filme etnográfico se ambos são considerados práticas autônomas e separadas às margens do cinema convencional? Um ensaio que oferece um olhar pertinente aos nossos propósitos é o ensaio Autoethnography: Journeys of the Self, na obra Experimental Ethnography: The Work of Film in the Age of Video (1999) da pesquisadora Catherine Russell. Baseada substancialmente, na experiência e na observação do "eu", isto é, na autobiografia, a autora situa o conceito de autoetnografia, para pensar realizações documentárias em primeira pessoa. Assim, dos modos de autorrepresentação onisciente, se abre passo para se tornar onipresente. Segundo a pesquisadora:

A autobiografia se torna etnográfica quando

o cineasta ou videasta entende sua história

pessoal inserida em grandes formações sociais e processos históricos. A identidade não é mais um "eu" transcendental ou essencial, pois será revelado, mas uma 'posta em cena da subjetividade', uma representação de si mesma, tal como uma performance. Na politização do pessoal, as identidades são interpretadas frequentemente através de vários discursos culturais, sejam estes étnicos, nacionais, sexuais, raciais e/ou baseados em classes sociais (1999 p. 276)

A autora ainda acrescenta, o sujeito inserido na "história", torna-se desestabilizado e incoerente, pois será um território de pressões discursivas e de articulações.

Algumas considerações podemos tirar do exposto até aqui: o conceito de autoetnografia é um caminho produtivo para o pesquisador da cultura, que se ocupa com a superação de divisões predominantes na reflexão teórica dedicada tanto às autobiografias ${ }^{10}$ quanto às etnografias do ponto de vista do nativo. É um convite a repensar as dicotomias, indivíduo/ coletividade, sujeito produtor de conhecimento/ objeto como continuidade e não como oposição. Todos esses temas mencionados são "temas/ objetos" dedicados à representação e que, por sua vez, não se devem dissociar aos modos de como se produzem e se difundem na sociedade. Considerar esse amplo leque de cinematografia como "etnográfico" é reconhecer novas fronteiras no dilatado horizonte da antropologia visual.

8 Método de pesquisa que envolve auto-observação e investigação reflexiva no contexto do trabalho de campo etnográfico e da escrita. O termo tem um duplo sentido, referindo-se à consideração reflexiva de um grupo ao qual alguém pertence como nativo, membro ou participante (etnografia do próprio grupo) ou ao relato reflexivo da experiência subjetiva do narrador (escrita autobiográfica com interesse etnográfico). Essa distinção pode ser confusa em algumas tradições de pesquisa. Às vezes, a autoetnografia é sinônimo de self-etnografia, autoantropologia, etnografia da performance. No entanto ela também é associada à narrativa de pesquisa e à autobiografia. Os usos do termo são inicialmente tratados em um percurso histórico pela antropóloga Deborah E. Reed-Danahay, que busca em outros autores a tratativa do conceitochave que ora está ligado aos relatos de vida como material de análise; ora é tomado como estudo feito pelo antropólogo sobre seu próprio povo; ora é concebido como a antropologia feita no próprio contexto social que a produz, com foco, portanto, na etnografia sobre a própria cultura. Ver Auto/Ethnography: Rewriting the Self and the Social. New York: Berg, 1997. $x i v+277$ pp.

9 Uma obra muito interessante que nos revela a existência de uma história do conceito de etnografia foi publicada recentemente pelo pesquisador Juliano José de Araújo. Cineastas indígenas, documentário e autoetnografia: um estudo do projeto Vídeo nas Aldeias. Bragança Paulista, SP: Margem da Palavra, 2019.

10 Vários autores denominam esta modalidade de documentário autobiográfico. Ver Lane 2002; Renov 2004 e Gabara 2006. O que parece ficar claro é que, os filmes autoetnográficos e em primeira pessoa, nem sempre são explicitamente, autobiográficos. Por mais subjetiva que seja sempre, a exploração da biografia do cineasta ou do antropólogo nativo, é uma busca menos importante nesses filmes do que se poderia esperar. 


\section{Teko Haxy- Ser Imperfeita $(2018,39$ ')}

$\mathrm{Na}$ parte introdutória mencionamos Teko Haxy - Ser Imperfeita como um documentário experimental sobre o encontro de Sophia Pinheiro (antropóloga, artista e cineasta) e Patrícia (professora e cineasta indígenas Guarani Mbyá atuante no projeto Vídeo nas Aldeias), uma mulher branca e uma indígena que o tempo todo exercitam o ato de filmar a outra e a si mesmas. Pelas entrevistas com Sophia, uma das autoras, sabemos que os registros fílmicos foram realizados sem um roteiro prévio, porém construídas a partir de temas sobre o feminino, trazidos originalmente por ela, e complementados por Patrícia. As imagens foram captadas de um cotidiano programado, além de planos subjetivos, utilizam muito planos com imagens desfocadas e invertidos (selfies) gerados de um dispositivo celular e de uma câmera Canon T5i. É um filme que coloca em cena os conceitos de documentário experimental em primeira pessoa e autoetnografia discutidas previamente neste artigo.

O filme é particularmente instigante para saber, como essas vozes estão construídas, do que falam essas vozes e, certamente, quais são as questões estéticas e subjetivas advindas desse documentário que deriva do ato de filmar a outra e a si mesmas e criar, experimentalmente, suas próprias narrativas, seus próprios espelhos. Para nossas análises fílmicas, qual procedimento utilizar? Uma abordagem fecunda é utilizar o filme como objeto" ${ }^{11}$ "o filme como campo de pesquisa, onde o analista, cineasta ou antropólogo, diante da imagem fílmica (base empírica), dedica-se à decifração" (REYNA, 2017 p. 39). Entendemos por decifração à observação e interpretação antropológica. Isto é, estudos, decifrações e interpretações de filmes em sua relação com o homem, tal qual como aparece no filme, da maneira como Claudine de France nos ensina: "o estudo do homem pelo filme significa não somente o estudo do homem filmável (...) mas, igualmente, o homem filmado, tal como aparece colocado em cena pelo filme" (FRANCE, 2000, p. 18). A abertura de uma nova relação de troca de informações, graças à presença do filme dá origem a uma nova proposta - a pesquisa exploratória - na antropologia do cinema ${ }^{12}$ : "O filme abre a pesquisa." (Id., 1989, p.309). Isto é, estudos, decifrações e interpretações de filmes em sua relação com o homem, tal como aparece colocado em cena pelo filme. Em resumo, tomando o filme como campo de pesquisa, nossa proposta é fazer etnografias fílmicas. Isto é, sob a "leitura" da tela e/ou no visionamento das imagens, construir interpretações, sempre provisórias, sempre passíveis de serem questionadas e/ou reconstruídas.

\section{Do dispositivo ao Documentário}

Se são inquietações deste artigo saber como se estabelece esse jogo relacional de conversa entre Patrícia e Sophia, onde as vozes, o corpo e a câmera, sempre estão ora com uma ora com outra, ou filmando e falando ao mesmo tempo subjetividades a duas, então, como analisá-lo? Anteriormente quando nosso texto conversava com Bill Nichols sobre a voz, o autor nos dizia que ela está intimamente ligada à forma como o cineasta expressa uma perspectiva, como ele transmite, representa sua visão sobre questões, problemas e características do mundo histórico. Isto é, a perspectiva é do cineasta

11 Sobre o cinema como objeto ler três artigos a respeito: dois do Paulo Menezes, Representificação: as relações (im) possíveis entre cinema documental e conhecimento. Rev. bras. Ci. Soc. [online]. 2003, vol.18, n.51, pp.87-98 ISSN 18069053 e Sociologia e Cinema: aproximações teórico-metodológicas. Revista Teoria e Cultura da UFJF v. 12 n. 2 jul. a dez, pp. 17-36. 2017 ISSN 2318-101x (on-line); e o terceiro, do Carlos P. Reyna, Antropologia do Cinema: as narrativas cinematográficas na pesquisa. Teoria e Cultura da UFJF v. 12 n. 2 jul. a dez, pp. 37-52. 2017 ISSN 2318-101x (on-line).

12 A respeito de pesquisas antropológicas a partir de filmes, sugiro a leitura das aproximações metodológicas e epistemológicas no Dossiê sobre Antropologia do Cinema publicado pela Revista Teoria e Cultura: Revista do Programa de Pós-Graduação em Ciências Sociais da Universidade Federal de Juiz de Fora, Instituto de Ciências Humanas, Departamento de Ciências Sociais. v. 12 n 2 julho-dezembro 2017, Juiz de Fora: Ed. UFJF, 2017. ISSN 2318-101x (online). https://periodicos.uff.br/index.php/TeoriaeCultura/issue/view/540 
filmando (interlocutor) o Outro. No modelo autoetnográfico, a perspectiva ou o ponto de vista é do Outro. Ele é, ao mesmo tempo cineasta e o Outro, cuja visão subjetiva é mediada pela câmera.

Sendo assim, para efeitos de nossas análises fílmicas nos apoiaremos em duas noções de cenografia geral utilizadas por Claudine de France em sua obra Cinema e Antropologia (1998). Primeiramente, a noção de mise en scéne, definida pela autora como apresentação fílmica, "O conjunto de leis em virtude das quais se define o que a imagem animada deixa necessariamente ver a qualquer espectador, e mais particularmente ao espectador antropólogo" (1998 p. 20). Certamente, isso responde aos procedimentos cinematográficos que foram utilizados pelo cineasta para colocar em cena os cenários ou os feitos e gestos das pessoas filmadas. A segunda noção, apoiada pelos traços de cinematografia documental denominada auto-mise en scène:

"que designa as diversas maneiras por meio das quais o processo observado se apresenta ele mesmo ao cineasta no espaço e no tempo. Esta mise en scène própria, autônoma, em virtude da qual as pessoas filmadas mostram de maneira mais ou menos ostensiva, ou dissimulam a outrem, seus atos e as coisas que envolvem, ao longo das atividades corporais, materiais e rituais é, todavia, parcialmente dependente da presença do cineasta. A auto-mise en scène é inerente a qualquer processo observado". (Op. cit., p. 405-406)

Em Teko Haxy, Sophia e Patrícia vão além do modelo autoetnográfico, pois o tempo todo elas experimentam o ato de filmar, fazendo com que o Eu, ora torna-se Outro, ora torna- se ela mesma, a partir da troca de quem está com o dispositivo e de quem está sendo filmada. Esse é o artificio ou protocolo das situações filmadas, ou dispositivo ${ }^{13}$. Quer dizer, nesse sistema de comunicação, cada uma tem uma distinção de funções de apresentação fílmica: Sophia com a câmera coloca Patrícia em mise en scène e que, por sua vez, apresenta a Sophia sua auto-mise en scène, e vice-versa. Essa lógica de apresentação fílmica é confirmada pelas próprias realizadoras em texto publicado para a plataforma digital Verberenas:

Diante da câmera, criamos personagens, mas também colocamos nossos assuntos mais íntimos. Assumimos uma estética íntima - nosso diário relacional - um experimento visual feito por nós, duas mulheres de diferentes mundos que criaram um mundo dentro dessas diferenças. Nossa automise-en-scène. (2019)

Em cena, ambas sempre descrevendo, comentando, falando o conhecimento que tem de si própria. Na imagem montada, vemos a autoimagem das personagens que nem um jogo de espelhos. A respeito do conceito de autoimagem a pesquisadora Sylvia Caiuby nos diz que:

“é um conceito relacional e se constitui, historicamente, a partir das relações concretas muito específicas que uma sociedade ou um grupo social estabelece com os outros (...) Essa autoimagem, por sua vez, implicará características não fixas, extremadamente dinâmicas e multifacetadas, que se transformam, dependendo de quem é o outro que se torna como referência para a constituição da imagem de si e mais, de como as relações com este outro se transformam ao longo do tempo". (1993 p. 27-28)

13 Utilizo essa noção para esta produção documental, ao modo que o Jean-Louis Comolli (2001) o usa, "de inventar pequenos 'dispositivos de escritura' para se ocupar do que resta, do que sobra, do que não interessa às versões fechadas do mundo que a mídia nos oferece. ” (2001 pp. 99-111) Outra referência que complementa à noção de Comolli nos é dada pelas pesquisadoras Consuelo Lins e Claúdia Mesquita quando o dispositivo se remete "à criação, pelo realizador, de um artifício ou protocolo produtor de situações a serem filmadas - o que nega diretamente a ideia de documentário como obra que "apreende" a essência de uma temática ou de uma realidade fixa e preexistente." No caso de Teko Haxy, o artificio foi experimentar o tempo todo, o exercício do ato de filmar a outra e a si mesmas. O objetivo inicial era de ser um filme realizado a partir de vídeo-cartas, para depois esboçar uma proposta autoetnográfica, porém cai no imprevisto e na permissão de uma mudança de ideias. 
É, nesse sentido, que o processo de realização do filme gera a troca entre culturas através de uma relação de alteridade, onde não há um pesquisador branco com conhecimentos superiores e nem um objeto "nativo" na posição inferior, mas sim uma relação horizontal, resultante de transformações a todo instante.

Assim sendo, do ponto de vista do dispositivo técnico, tentaremos colocar em evidência a relação de correspondência entre Sophia e Patrícia (mise en scène e auto-mise en scène), para, nesse jogo performático e autoetnográfico de simetria fílmica, encontrarmos em suas vozes, a fonte de narratividade própria da qual precisamos tornar compreensível o que elas falam. Essa estratégia de mise-en-scène se justifica haja vista sua afirmação central de que a voz e imagem são indissociáveis no cinema documentário.

Teko Haxy pode ser dividido em sete sequências que consideramos mais importantes: a primeira, é constituída de vários fragmentos que mostram a imagem subjetiva de Patrícia a sua chegada ao aeroporto de Quebec, um dia de agosto de 2015; o deslocamento dela em uma canoa com motor dirigindo-se ao encontro com Sophia, também câmera subjetiva, aqui, no entanto, ela faz um leve movimento de câmera para se mostrar (autoimagem) e; finalmente, Patricia, Sophia, Ariel e Géssica de carro na estrada caminho à casa de Patrícia. A imagem desta última sequência é, particularmente interessante, porque, Ariel (esposo de Patrícia) faz uma selfie em grupo. Além de mostrar para o espectador a imagem do mundo histórico invertido (o motorista do lado direito e a faixa de percurso do lado esquerdo), nos apresenta os atores sociais do documentário.

A segunda parte é um outro tempo e espaço, em junho de 2016, e as atividades se desenrolam na aldeia Ko’enju. Logo de manhã, um dia de frio, vemos a Patrícia colocando em cena o rosto de Sophia que, após ter acordado, se dirigirem, ambas, à escola onde ela dá aulas. Os registros fílmicos desse pequeno percurso em plano sequência são imagens subjetivas de Patrícia feitas no celular. Em segundo plano, o galo canta e a voz off em língua Mbyá guarani ela nos diz: “o nome dessa aldeia é ko’enju, agora estou indo pra escola, está frio, esta estradinha vai até a escola onde dou aulas, faço esse trajeto diariamente durante a semana". A imagem faz uma pequena pausa e se desvia em direção à casa de sua mãe dizendo: "aqui é a casa de minha mãe, eu sempre passo aqui rapidinho antes de ir pra escola, para tomar café". A sequência termina em um plano aberto em contraluz, mostrando, na sombra (Frame 01), a troca do dispositivo técnico (celular) com Sophia. Esse frame funciona como uma alegoria daquilo que virá doravante acontecer no documentário, ora Patrícia é a realizadora ora a Sophia.

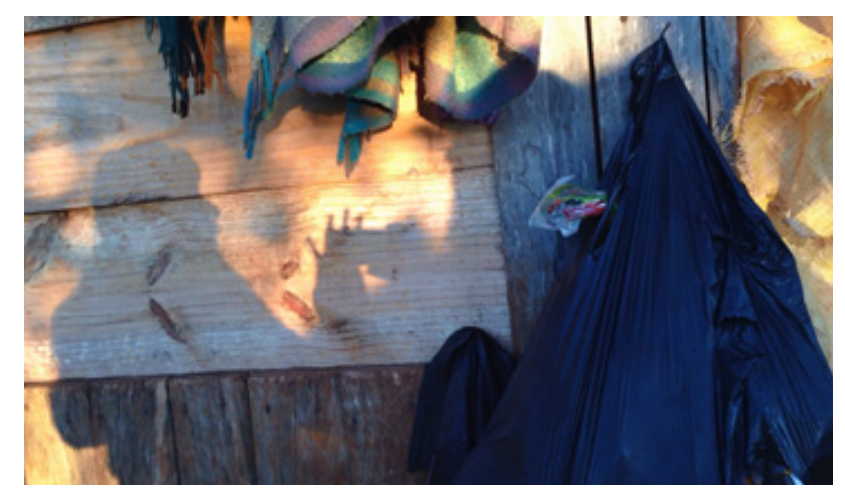

Frame 01

Percebemos nesse plano sequência de 01':15”, a adoção de dois comportamentos de Patrícia e Sophia: a) a primeira, de significação social; vemos os deslocamentos que Patrícia realiza diariamente para desempenhar sua prática docente em sua comunidade. Uma das caraterísticas da subjetividade é a empatia que cria com o espectador, neste caso, pela voz dela sabemos que é professora, o conhecimento disso nos causa afetos e, b) de estratégia fílmica; para dar continuidade ao plano sequência que, após a troca da câmera com Sophia, a imagem ainda mostra a entrada de Patrícia na casa de sua mãe. Por essa estratégia, o olhar subjetivo de Patrícia, passa ela mesma a ser mise en scène na sequência final. Quer dizer, um duplo papel: o de filmar a ser filmado, e de cineasta a personagem.

A terceira parte, nos mostra o desenrolar das angústias e técnicas de matar uma galinha. São três sequências: se inicia com o lavado da panela por parte de Sophia (Patrícia filmando); continua 
com a colocação da panela com água na fogueira e; finaliza com Patrícia matando a galinha. Estas duas últimas sequências colocam em prática o conceito de dispositivo, ou seja, o ato de filmar uma a outra. Aqui são necessárias algumas interpretações e reflexões: a de ordem cultural, a qual é Patrícia que instrui a transmissão de saberes dessa atividade material. É ela quem comanda os registros fílmicos para colocar em cena a Sophia, e a orienta como lavar a panela, como acender o fogo e como matar a galinha. São atividades cotidianas na aldeia, nada de grandes temas culturais preexistentes. No entanto, uma sequência que nos revela a presença de um conceito que, ao que parece, guiava a experiência até esse momento, é quando Patrícia entra em plongée em cena, para ensinar na prática a Sophia, como se acende o fogo, e ela diz se dirigindo a Sophia: "então, filma agora para fazer vídeocarta" (Frame 02).

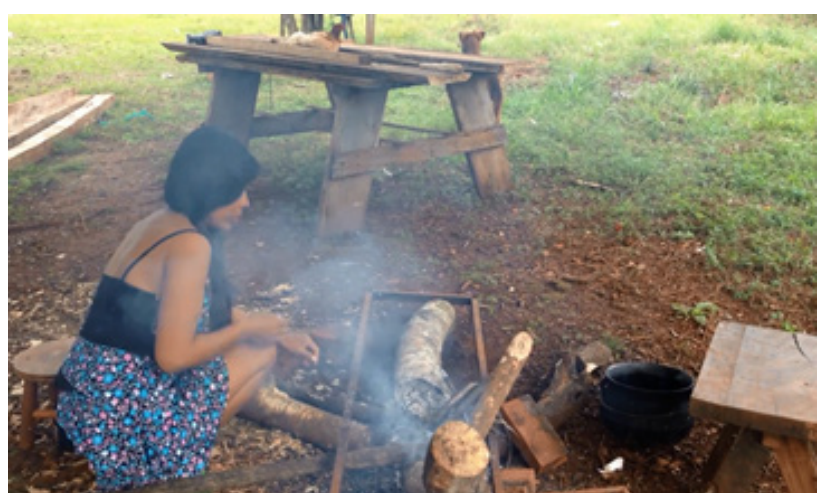

Frame 02

Duas elucidações podemos extrair dessa frase: Patrícia pensa que a câmera está desligada e, convoca a Sophia a filmar o que ela chama de vídeo-carta. Sophia, por sua vez, está com câmera ligada, permitindo o registro do corpo e a voz, mesmo em tempos considerados repetitivos ou fracos. Isto é, nem sempre a sua mise en scène coincide com a auto-mise en scène da Patrícia. As falas, neste caso, revelam a doação de Sophia ao exercício cinematográfico da escuta e ao tempo do outro; a filmagem torna-se uma atividade não apenas dos olhos, mas dos ouvidos, o tempo todo o dispositivo no documentário experimental também é construído desses momentos. Sabemos então, pelos registros contínuos que Sophia faz dos comportamentos destinados à atividade de matar a galinha que, as duas realizadoras ainda tinham em mente pôr em prática o conceito de vídeo-carta ${ }^{14}$.

A quarta parte do filme, são sequências realizadas ao pôr do sol, à beira do rio Uruguai, em Porto Mauá, na fronteira Brasil - Argentina, em julho de 2016. Com a câmera ligada, Sophia, novamente, surpreende Patrícia ao início das atividades desse dia. A imagem enquadrada ${ }^{15}$, tremida e em movimento, revela a voz off de Patrícia que supressa diz, "Ah, já está gravando já". Sabemos pelas vozes delas que, calibram (configuram) o setup da câmera para os registros que continuarão a seguir. Após um corte, Sophia com câmera alta total ${ }^{16}$ (Frame 03), mostra brevemente Patrícia, com um sorriso ingênuo, deitada no chão, dizendo "Tenho preguiça de traduzir". Esse breve comentário indica que, o relato que ela iria começar, gostaria de fazê-lo em guarani, pois "as palavras em guarani são mais profundas que o português". Coloca assim, em primeiro plano, sua marca identitária do

14 Não é pretensão fazer um levantamento das diferentes obras documentárias que tratam a respeito das vídeo-carta. Um trabalho que debate esse conceito é a pesquisa de Coraci Bartman Ruiz, Documentário-dispositivo e vídeo-cartas: aproximações. Nas próprias palavras da autora a vídeo-carta "é uma invenção, um artifício criado pelo documentarista para realizar um documentário, se colocar em relação com outro, colocar outros em relação entre si, criar imagens, sons, narrativa" (2009 p. 42).

15 François Truffaut dizia que as pessoas sempre olham em plano geral, o contrário acontece toda vez que olhamos com a câmera, pois podemos selecionar o plano, portanto, o espaço que queremos selecionar/mostrar. Essa seleção divide o espaço em dois planos: o que se vê e o que não se vê. Isto é, o uso da câmera exige uma seleção do espaço (enquadramento) e supõe deixar parte da realidade fora do quadro (fora-do-campo). Ver declaração de François Truffaut em TRUFFAUT, François El cine según Hitchcock, Madrid, ed. Alianza, (1998). Por estar ligado ao conceito de plano, na teoria e na história do cinema sempre suscito diferentes abordagens e debates. Para nossos propósitos o enquadramento estará vinculado ao espaço fílmico, tal como é apresentado na tela, entre dois cortes e, mostra as manifestações visuais e sonoras delimitadas pela imagem.

16 Esse ângulo de enquadramento devemos interpretá-lo em seu sentido técnico e não ideológico, pois é em esse momento que a Patrícia começa a discutir sobre as barreiras de tradução de sua língua nativa. 
povo Mbyá-Guarani. Sua fala nos revela sua dor profunda a respeito da conquista, da colonização, destruição da natureza e da herança indígena que o homem branco tenta apagar.

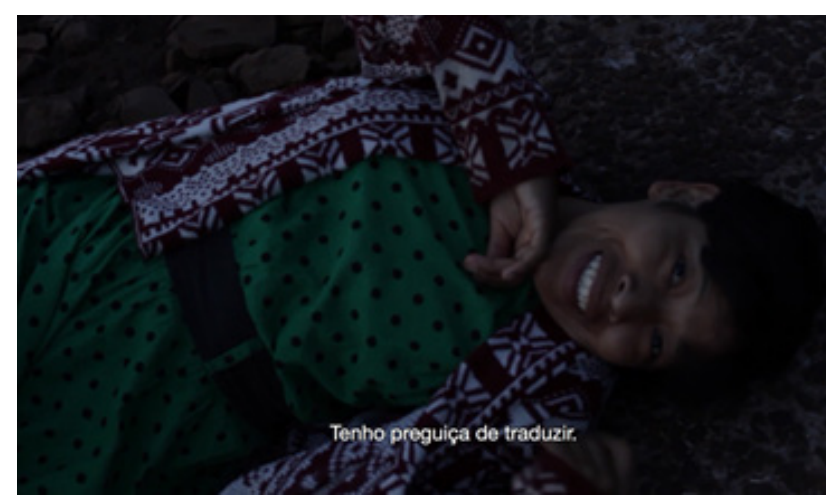

Frame 03

O relato continua, Sophia mostra em close o rosto grandioso de Patrícia (Frame 04). O plano tem o mesmo nível do olhar em ambas, o que possibilita o conhecimento de suas demandas. Entre as já mencionadas, também narra a dificuldade que os indígenas enfrentam para atravessar a fronteira, onde, o ponto de vista indígena não se encaixa nas expectativas do Estado. Nas pesquisas particulares de Sophia Pinheiro, nos confirma essa interpretação quando diz "as fronteiras na realidade não existem - são imaginadas, impostas pela colonização para o controle identitário, político e territorial dos povos tradicionais. A fronteira não é meramente espacial, é um afastamento da compreensão do Outro." (2017, p. 22)

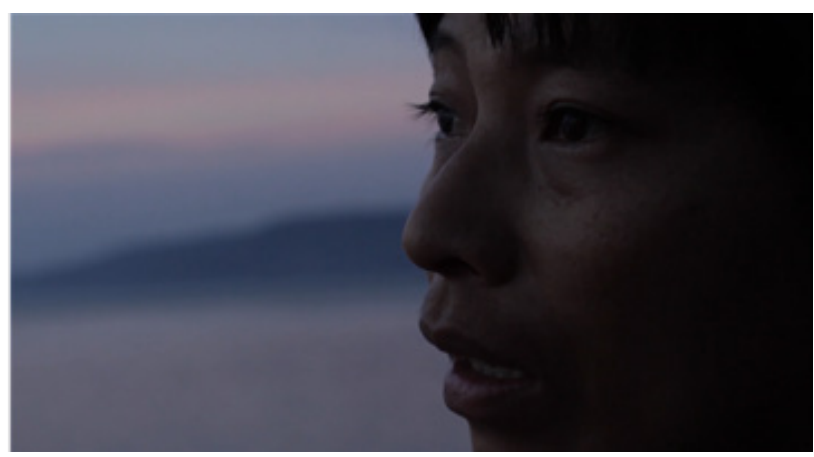

Frame 04 que também está fora de campo, apesar sabermos de sua presença em posição de câmera. Para lembrarmos, Jacque Aumont (1995) distingue sobre o que está contido na imagem como campo e o que está fora do enquadramento como "fora de campo".

Uma reflexão ambivalente das imagens a respeito desta quarta parte do filme diz respeito ao seguinte: ainda que, a câmera em vários momentos se revele como agente interlocutor do espectador, percebemos que os enquadramentos de aproximação e intimidade da mise en scène da personagem (ator social), verifica também, exatamente uma descrição de subjetividade que Sophia tem de Patrícia e permite não só a identificação do espectador com ela, mas uma objetivação de sua imagem social e de suas demandas.

$\mathrm{Na}$ sequência que se inicia no minuto 18:23 e vai até 20:52, começa a quinta parte que acreditamos ser fundamental sua análise e interpretação antropológica. Diz respeito ao desenrolar da atividade corporal de tomar banho como prática de purificação. Quem comanda os registros fílmicos é Sophia, desde a saída de carro da casa do Ariel até o final da sequência. Os desdobramentos desses comportamentos são da manhã de um dia gelado em junho de 2016, Patrícia, Géssica, e Ariel vão tomar banho ao rio Inhacapetum, perto da aldeia Ko’enju. Ariel é quem mergulha primeiro e sai rápido. Logo, Patrícia com o corpo parcialmente nu, vai entrando aos poucos e solicita, em língua guarani, à entidade do rio levar "toda minha brabeza e minha preguiça" "leva tudo que eu tiver de ruim" (Frame 05). O mesmo acontece com a Géssica, a imagem acompanha o mergulho dela, mas em voz off e alta, Patrícia repete as mesmas preces, mas como se trata de sua filha, acrescenta "Leva a minha mania de chorar por qualquer coisa”. Nesta última atividade, a mãe solicita à filha repetir as preces que ela fala para a entidade do rio.

Nessa parte da sequência, Patrícia em nenhum momento olha diretamente para a câmera, pelo contrário, atribui um olhar distante, de algo fora do quadro, ou em direção a Sophia, 


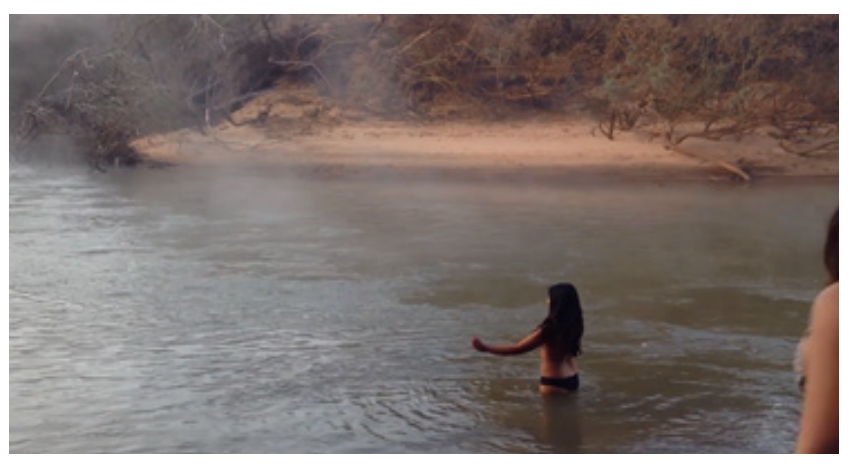

Frame 05

Com essas práticas de purificação realizadas por Patrícia e Géssica, duas significações são colocadas em cena: primeiro, ambas realizam suas intenções, ou à maneira mais profunda, sua própria consciência do mundo e das coisas, invocando sistematicamente, e segundo uma lógica do gesto ritual, os seres ou um ser em particular, no qual acreditam encontrar a forma de realização perfeita. Com suas preces, celebram alianças, traduzindo um pacto ou a simples expressão de uma união íntima entre seres que habitam o mesmo espaço comunitário. Então, como extrair os componentes desse sistema de comunicação entre Patrícia e a entidade que mora no rio? Segundo Luc de Husch (1974), atento à função de comunicação do rito, a noção do destinatário ocupa um lugar central. Pelo mencionado, o destinatário (Tupã ${ }^{17}$ ) é o primeiro elemento de referência e de orientação das preces de Patrícia, a ele convergem todos os seus pedidos e com ele se engaja um diálogo verbal.

Ao que tudo indica, é o único momento no filme em que a auto mise-en scène de Patrícia não tem correspondência com a mise en scène de Sophia, pois está orientada a outro destinatário, desta vez invisível, como o mostra visualmente o Frame 5.

A sexta parte é um dos momentos específicos, intensos e marcantes deste documentário experimental, trata da apresentação fílmica do diálogo entre as Patrícia e Sophia, onde esta última desaba a chorar, e revela sua tensão ao fazer o filme, questionando se não está extrapolando os limites éticos da imagem e de si mesma. Ela acredita que está pressionando Patrícia a fazer coisas que ela não quer. São cenas que acontecem em maio de 2016 na aldeia Ko'enju, conjeturamos que seja a casa de Patrícia. Quem dirige a cena é Patrícia, com câmera subjetiva coloca Sophia em close up, são imagens às vezes focadas às vezes desfocadas, os dizeres dessa fala passo a transcrever:

\begin{abstract}
"Eu fico nervosa, porque eu não sei se estou te pressionando, te fazendo fazer coisas que, às vezes você não quer, que às vezes não pensou em fazer isso...entendeu? (...) Não sei, tem toda a questão da imagem também, eu fico sempre tomando cuidado para não...explorar nem nada, não sei, assim. E aí eu fico sem saber porque você não fala direito... (risos em off de Patrícia), você é muito fechada as vezes...passa com uma cara (...) Não sei eu gostaria que você realmente me dissesse, 'não, eu não quero fazer isso' ' sim, eu quero fazer isso ... (risos em off de Patrícia)"”
\end{abstract}

Esse relato em forma de desabafo e com dúvidas, é uma provocação rouchiana que obriga a Patrícia a responder e interagir com Sophia. A partir dessa intervenção da câmera em Sophia, provoca reações reveladoras no "conflito" e nas trocas entre quem filma e quem é filmada. Logo, Patrícia, fora do quadro, mas em voz off responde:

“(...) Realmente, Sophia, não é nada com você, mas é que...Eu fico tipo ai...Eu quero, sei lá...me fechar num lugar só, ficar bem sem ouvir nada, assim... (...) todas essas coisas vão se acumulando pra mim, no meu corpo...Sei lá pra minha alma, pro meu espírito (...) Mas antes não, eu ficava muito, muito doente. Eu ficava sempre doente. Quem me cuidava era o Ariel ou às vezes minha mãe, quando tava aqui. Então, eu acho que...meio que eu quase caí de novo nessas coisas...Eu tava sempre doente...

17 Em pesquisas realizadas a respeito da significação de Tupã na cosmovisão Mbyá Guarani, vemos que ele é uma entidade que mora no céu e envia trovões, relâmpagos e chuva. Para nossa interpretação nos valemos do significado que Judith Shapiro utiliza. Ver "From Tupã to the Land without Evil: The Christianization of Tupi-Guarani Cosmology." American Ethnologist 14, no. 1 (1987): 126-39. Accessed May 27, 2020. www.jstor.org/stable/645637. 
(...) eu lembro que tinha uns cinco anos, que meu tio estava me levando pra Tamanduá. Ai depois de alguns anos fui de novo. (...) Eu me lembro que minha mãe falo que ela ia voltar pra Kuña Piru e perguntou se eu queria ou não, aí não me lembro o que eu respondi, se queria ou não, não me lembro. Só me lembro depois que eu acordei de manhã, procurei pela minha mãe e ela não tava, alguém falou: tua mãe já foi embora, agora você vai ficar aqui em Tamanduá, porque você foi na escola e ela te deixou aqui...Me lembro que eu fiquei com saudade. Desde que voltei com nove anos, eu fiquei sempre doente. Eu tinha qualquer tipo de doença, sabe? (...) Então, a primeira que eu me lembro é que não estava caminhando mais (...) até os onze anos (...) Logo depois que voltei de Tamanduá, aí sempre estava em Opy, na casa de reza”

Sophia surpresa rebate: "você ficou dos nove aos onze sem caminhar?"

Patrícia continua:

"sim, tipo...era uma bola que saía e depois aquela bola sumia (...) caminhava um pouquinho e ela saia de novo. Aí lembro que fui no hospital várias vezes também...Aí, de uns anos pra cá, acho que fiquei um pouco mais forte” (Frame 06)

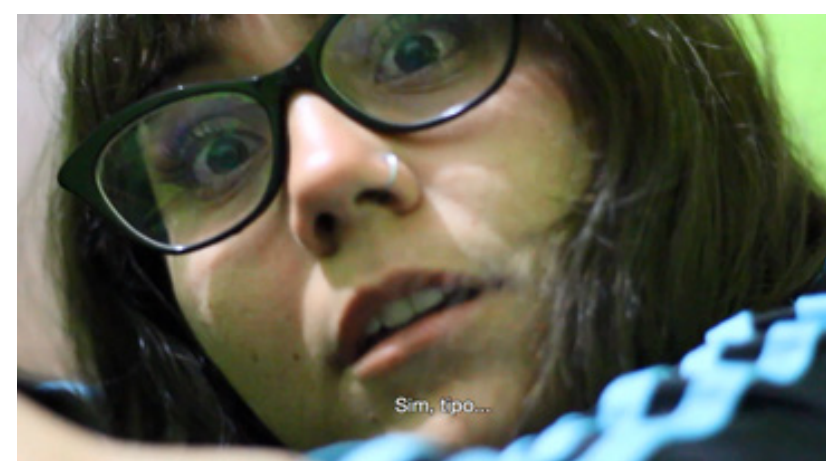

Frame 06

Tem uma pequena pausa, silêncio e, Sophia em sintonia com a narrativa de Patrícia diz:

“Não sei, parece que você está contando a minha história aí. Porque quando era pequena também ficava muito sozinha, né? Minha mãe me crio sozinha, filha única, mas... sem pai e tal...Então, ela sai para trabalhar e me deixava muito sozinha...eu assistia muita TV (...) eu não entendia porquê e tal... Depois que a gente cresce é que a gente entende. Tanto que não me lembro nada de minha infância.. assim, acho que cortei, limei isso de minha vida (...). Quando nasci, tive pneumonia. E aí minha mãe...ela meio arbitrária com questões de saúde, principalmente, depois que tive meu problema de saúde sério... Ela me dava muito mamadeira, muita coisa e aí minha avó fala que isso esticou meu estômago, então era meio gordinha quando era pequena."

Os diálogos acima reproduzidos merecem algumas breves reflexões: são, discursos autobiográficos femininos, que contribuem para trazer à tona sensibilidades e subjetividades "como espaços comunicativos e discursivos através dos quais ocorre o 'encontro de subjetividades', a interação de subjetividades em diálogo" (VERSIANI, 2005, p. 87). Patrícia e Sophia mergulhando nas características intersubjetivas da experiência e da memória, colocam o diário íntimo fílmico ${ }^{18}$, como lugar comum de fala. Catherine Russel sugere através dessas características, um repensar do conhecimento etnográfico, onde "o papel da identidade nesses filmes exige uma noção ampliada de etnia como formação cultural do sujeito." (2010, p. 239)

Em termos dos registros fílmicos experimentais, mesmo que Patrícia não esteja na imagem, a sua voz off coloca em cena jogos de mise en scène muito singulares. Nessa sequência, uma característica fundamental do dispositivo construída por Patrícia, que é a não-presença e presença simultaneamente do corpo e da fala, respectivamente, dela. Essa nãopresença é revelada pelo olhar de Sophia que a observa o tempo todo. À vista disso, a câmera ocupa o lugar do corpo não presente, porque é ocultado de Patrícia. Esta forma narrativa é uma característica da subjetividade definida como

18 O diário fílmico, na premissa de uma biografia pode ser entendido como um "cinema pessoal" e "moldado como uma forma de etnografia experimental" (RUSSEL, 2010, p. 239).) 
ocularxização interna primária ${ }^{19}$. Desse modo, em função do dispositivo narrativo, o "lugar" de onde Patrícia transmite suas lembranças e suas dúvidas a Sophia, é um lugar ocupado pelo espectador. Quer dizer, uma declaração de que o espectador pode ocupar um papel ficcional dentro de um filme documentário, mesmo experimental. As interações subjetivas desta sexta parte ainda continuam. Surge então, a indagação sobre padrões estéticos na cultura indígena e a ocidental. Sophia olhando para a Patrícia (câmera) pergunta:

“você acha que esses padrões estéticos Juruá, eles interferem no seu corpo? Igual eu disse da questão de ser gordinha quando era pequena...Ou até mesmo hoje de eu ser um pouco...mais cheinha assim, gordinha mesmo, acima do peso, sei lá...”

A voz em off de Patrícia, desfocando o rosto de Sophia, responde:

"Eu acho que Nhanderu Kuery mandou a gente do jeito que gente é, para a gente se aceitar assim. Eu não sei o que eu mudaria no meu corpo, no meu rosto... Eu não tenho nada para mudar, mas sei lá, acho que nenhum Guarani faria isso. Talvez eu esteja enganada, mas eu acho que nenhum indígena, na verdade. Eu fico as vezes pensando por que os brancos fazem isso...Por que querem ser perfeitinhos? $\mathrm{O}$ que é perfeito? O que é perfeito para os não-indígenas (simetria)? Ser uma pessoa perfeita, ter um rosto perfeito...Por que pra gente, perfeito é não ter maldade. Mas acho que o que realmente vale a pena definir como beleza (Frame 07 e 08) ou definir como perfeito, é o amor que você tem em seu coração. Que também é muito difícil, às vezes, para uma pessoa conseguir tudo isso."

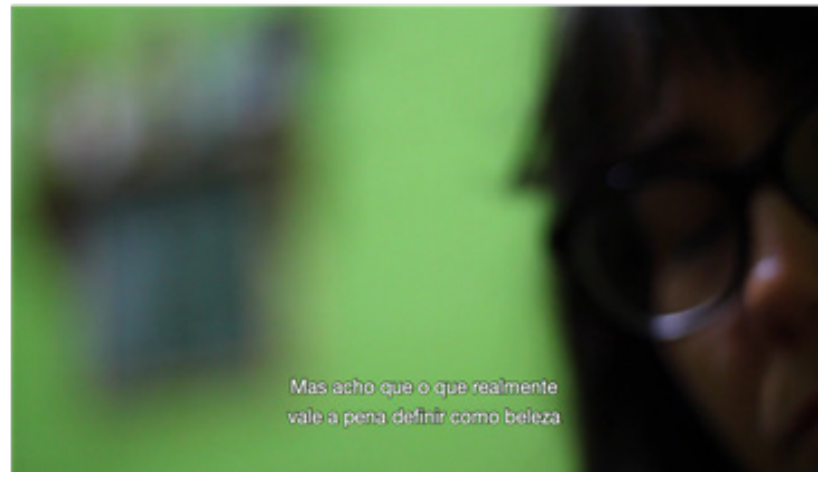

Frame 07

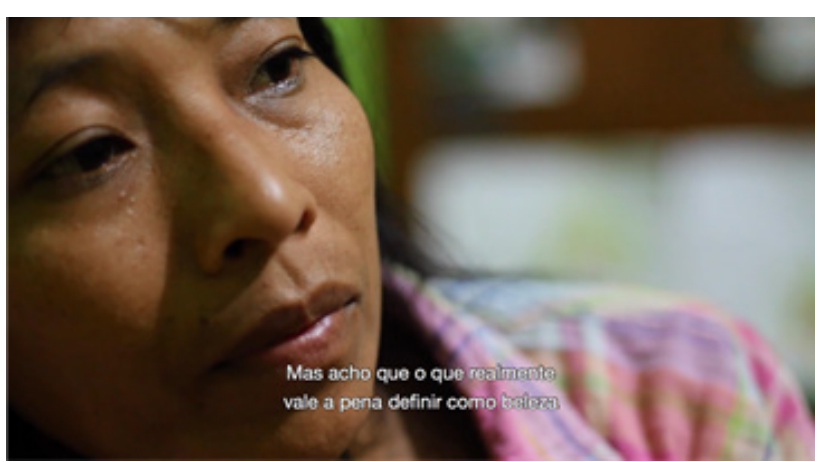

Frame 08

Duas observações sobre estes diálogos: sobre os padrões estéticos impostos pela sociedade inserida na cultura ocidental, quando interpelada à subjetividade de Sophia, "você acha que esses padrões estéticos Juruá, eles interferem no seu corpo?" Patrícia diz: "perfeito é não ter maldade". Tudo indica, que uma das particularidades entre os Mbya é a existência de cuidados nos diferentes períodos da vida que são destinados a fixar a alma no corpo. Essa voz representa o principal elemento identificador de um ser Mbyá-guarani e coloca no cerne de sua tradição, dicotomias natureza-cultura e sociedade-sobrenatureza, que os conecta diretamente com as divindades enquanto vivem em Teko Haxy, segundo Patrícia Ferreiro Pará Yxapy, na aldeia imperfeita.

Da estrutura de montagem ${ }^{20}$ desta sequência, surge outra possibilidade de construção não narrativa no campo do documentário experimental. A saber, no minuto 33'35", escutamos a voz de Patrícia dizer: "mas acho que o que realmente vale a pena definir como

19 André Gaudreault e François Jost. A narrativa cinematográfica. Brasília: Editora da UnB, 2009. P. 170

20 Além de Patrícia e Sophia, Tatiana de Almeida também possui um papel importante no filme, como montadora, quem ajuda conduzir e transformar a narrativa do filme. Tatiana também é atuante no projeto Vídeo nas Aldeias. 
beleza”. É, a voz de uma frase que une dois planos. Começa com o olhar embaçado subjetivo de Patrícia (campo) (Frame 07) e termina com o olhar nítido subjetivo de Sophia (contracampo) (Frame 08), a sutura desses dois planos é dada pela voz de Patrícia, que dá continuidade à voz e descontinuidade à imagem. Se o campo/ contracampo é um dispositivo importante de construção do espaço fílmico narrativo, seria uma boa oportunidade de se interrogar sobre, como a voz (áudio) coloca em cena, a costura de duas subjetividades no documentário experimental?

Uma possível resposta é dada pelo entendimento da montagem como elemento utilizado no documentário experimental. Vejamos; se a voz contínua (áudio) começa no campo subjetivo de Patrícia (plano A) e termina no contracampo subjetivo de Sophia (plano B), pelo corte (montagem) o dispositivo irrompe a cena de A e, o espectador, abruptamente, sai de seu transe e deixa de ser o "lugar" onde Patrícia transmite suas subjetividades. Diferente da narrativa clássica cinematográfica que objetiva encobrir as marcas de sua materialidade/construção, em Teko Haxy, a montagem expõe as entranhas de seu dispositivo e permite mostrar a cara de quem fala em subjetividade (autoimagem). Se mergulharmos nas interpretações antropológicas, lembremos novamente a obra Jogos de Espelhos (1993) de Sylvia Caiuby, algumas explicações do espelho como metáfora para a sociedade ver o processo de transformação que sofre com o contato de diferentes grupos sociais, através da sua autoimagem, mas também se pode perfeitamente substituir o espelho pelo cinema e analisar as imagens nele produzidas. Ver-se-á histórias das mulheres apagadas na constante tentativa de se afirmarem como sujeitos e agentes ativos.

A última cena que selecionamos para nossas análises, trata dos desdobramentos dos registros fílmicos do desenrolar da aplicação de um saber tradicional Mbyá, em um processo terapêutico do uso de ervas como tratamento para doenças e dores no joelho. A mise en scène destes registros fílmicos foi feita pela própria Sophia e, o motivo ela o menciona nos diálogos intersubjetivos que tem com a Patrícia no minuto 34'12". Vejamos, ao rever as imagens do filme, Sophia em contra plongée e em close up, nos lembra que aos 13 ou 14 anos de idade, por motivos que ela desconhece, começa a sofrer de artrite nos joelhos. A pesar dela ter passado por diferentes tratamentos convencionais e alternativos, ainda hoje a afeta (Frame 9).

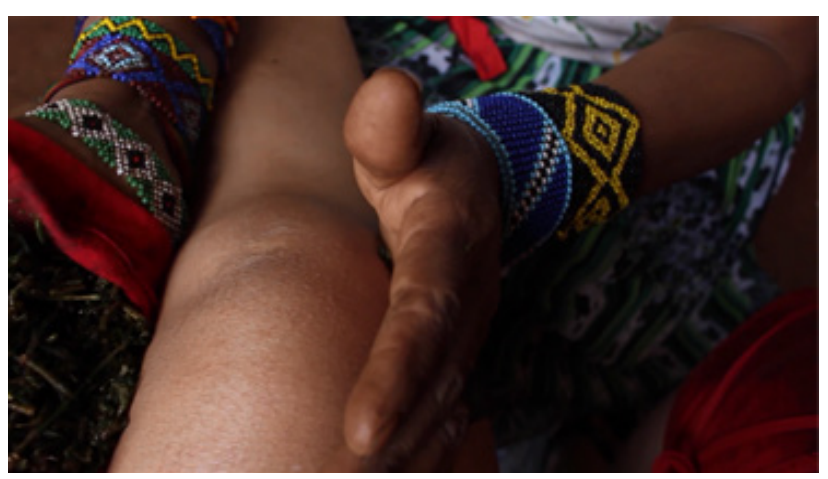

Frame 09

As cenas desta sequência são imagens subjetivas de Sophia e nos revela as manipulações que Elsa, mãe de Patrícia, realiza na aplicação da erva pengué-po a ${ }^{21}$ (remédio para fraturas) no joelho da própria antropóloga/cineasta. Isto é, a mise en scène dos gestos e posturas da técnica material ${ }^{22}$ de Elsa, além de serem desdobramentos de manipulações no próprio corpo de Sophia, também são imagens apresentadas para o espectador do ponto de vista da própria cineasta. Isto é, o ângulo, o enquadramento e a duração temporal dessas operações oferecem outra opção às práticas que o etnólogo-cineasta tem, toda vez que precise colocar inteligível manifestações sensíveis da atividade humana, aqui denominada etnocinematografia de si. A meu ver, essa prática

21 Cadogan, León. En torno a la Aculturación de los Mbyá-Guaraní del Guairá, in América Indígena, No. 2, vol XX, México, 1960. Pp. 133-148

22 Técnica material definida assim por Claudine de France "Uma das particularidades das técnicas materiais consiste precisamente no duplo caráter exterior e material de seu objeto (a exterioridade é sem dúvida de uma importância capital para o cineasta colocado em cada instante diante da escolha de um enquadramento e de um ângulo que junta ou separa no espaço os elementos do conjunto eficiente composta pelo agente e seu dispositivo" Cinema e antropologia, 1989 . p. 61. 
autoetnográfica é uma contribuição desta etnocineastaparaocondutodeinterconhecimento que é a situação antropológica. Ela oferece outra possibilidade àqueles que lançam mão do filme para suas pesquisas etnográficas no sentindo inverso, desde que o olhar seja do próprio nativo.

\section{Considerações finais}

Este trabalho é uma análise fílmica que toma como base empírica o filme Teko Haxy e, em seu discurso experimental procuramos desvendar e jogar alguma luz sobre as seguintes perguntas: quais são as formas estilísticas e estéticas que um documentário oferece quando se decide experimentar o "eu" feminino como exercício performático e autoetnográfico de simetria fílmica? Isto é, colocamos em evidência a relação de correspondência entre Sophia e Patrícia (mise en scène e auto-mise en scène) e vice-versa e, nesse jogo de espelhos, tentamos encontrar em suas vozes, a fonte de narratividade própria da qual precisamos para tornar compreensível sobre o que elas falam.

Buscando responder a essas perguntas percebemos que, na sua construção fílmica, existem hibridismos estilísticos naquilo que chamamos de experimental. Planos sequências subjetivos caros ao "realismo" coexistem com autossublinhamentos (autoimagem) na sua construção não-narrativa ou, como diria André Parente (2000) “o fílmico não se opõe ao narrativo". Por exemplo, na análise de nossa segunda sequência, do olhar subjetivo de Patrícia, em plano sequência, passa a seu autossublinhamento do rosto (autorretrato) pela passagem da câmera às mãos de Sophia. Por esse movimento fílmico o plano sequência além do percurso que Patrícia organiza na imagem, também mostra sua entrada na casa de sua mãe. Nesse exercício experimental, Patrícia passa ser mise en scène na sequência final. Quer dizer, Patrícia desempenha um duplo papel: de filmar a ser filmada, de cineasta a personagem.
O subjetivismo de Patrícia converte o habitual e o cotidiano omitido em algo extraordinário.

Outra constatação estética e estilística é dada pelas noções de mise en scène e automise en scène, como relações inerentes a toda apresentação fílmica. Estas, em Teko Haxy, mesmo no exercício da experimentação parecem não fugir às manifestações que a profilmia ${ }^{23}$ oferece. No filme, esses atos da terceira e quarta parte, longe de eliminar ou abolir na montagem, a imagem final nos apresenta os comportamentos imprevistos e inesperados de Patrícia, quando é pega de surpresa pela presença da câmera ligada. Atos definidos por J-L. Comolli de habitus assim: "trama de gestos aprendidos, de reflexos adquiridos, de posturas assimiladas (...) segundo os campos onde a pessoa filmada intervenha (...), ela se veja engajada e tomada nas mise-en-scènes (2008 p. 84). Esses habitus sempre oferecerão recepções contraditórias do espectador, terão alguns que possam entender sua significação, terão outros que acharão desnecessárias suas inclusões na montagem final.

A inversa também é verdadeira, no desenrolar da quinta sequência, a falta de correspondência entre auto-mise en scène de Patrícia com a mise en scène de Sophia é dada pela presença de outro destinatário às preces oferecidas pela Patrícia. Explicamos, o primeiro elemento de referência e de orientação de Patrícia é um outro destinatário, o Tupã, a ele são oferecidos os gestos e as palavras de sua auto-mise en scène. É um momento de pura descrição etnográfica, mesmo nas práticas experimentais de apreensão cinematográfica de Sophia e Patrícia, ela é submetida à lei cenográfica de saturação de toda descrição fílmica, onde segundo Xavier de France noz diz que, "mostrar uma coisa significa mostrar outra simultaneamente" (1982). Isto é, mesmo na execução das regras do dispositivo, o fluxo contínuo de comportamentos, gestos e manipulações das personagens na imagem, sempre, aparecem atividades esfumadas ou documentário que adquire formas mais ou menos agudas e identificáveis” (1998, p. 412). 
colocadas em segundo plano ou terceiro plano.

Ainda duas questões sobre a montagem em Teko Haxy. A primeira, sobre a montagem final, não existe um fio condutor do desenrolar das atividades das cineastas, não existe uma à linearidade temporal que permita um início, meio e fim dos atos e comportamentos na execução dos protocolos do dispositivo. Não existem grandes temas preexistentes de interpretação ou reinterpretação antropológica. $\mathrm{O}$ único que preexiste são seus personagens. Como diria André Parente (2000), o filme, a sua maneira, torna-se o próprio acontecimento. Seus conteúdos estão baseados nas estratégias de provocação e de escolha do dispositivo: no filme, a prática de se filmar uma a outra e a si, e suas contingências. Sobre a montagem das sequências, chamaríamos de montagem livre, como documentário nãonarrativo, são nove sequências-experiências, independente da ordem cronológica sempre encontraremos duas cineastas ensaiando $\mathrm{e}$ insurrecionando à narrativa documentária.

Contudo, pelas nossas análises fílmicas, a despeito de ser uma proposta experimental, existe um elemento etnográfico descritivo passível de uma interpretação antropológica. Nos referimos ao ritual de purificação praticada por Patrícia, essa sequência confirma que em determinados momentos o descritivo etnográfico faz parte do dispositivo. Ambivalências das escrituras cinematográficas.

Finalmente, do que falam as cineastas? Perante os protocolos do dispositivo, o jogo relacional de provocações entre Patrícia e Sophia, e a inscrição de subjetividade das cineastas, se impõem sobre qualquer outras mostrações dos processos e mecanismos dos quais se constrói Teko Haxy.

As falas de Patrícia às vezes em voz off, às vezes em autorretrato, às vezes pela mise en scène de Sophia poderíamos organizá-las da seguinte maneira: no enraizamento de sua existência Mbyá Guaraní e as injustiças que sua cultura sofreu e ainda sofrem pela colonização, pela presença do branco, pelo abandono do Estado; a intenção é combater e desmontar os discursos hegemônicos que ditam as formas de viver e criar obedecendo à incerta condição de sentir-se "uma estranha no ninho" em seu território construído por estrangeiros. As escritas sobre si na imagem, são discursos identitários. As percepções e as experiências íntimas femininas inscritas na memória individual de Patrícia é memória coletiva dos Mbyá, portanto, são narrativas convertidas em formas de resistência. Paul Ricoeur (2012) estava certo quando dizia que, toda história do sofrimento clama por vingança e exige narração. A consciência da relação de poder que ela tem sobre a câmera (apropriação) e a invenção do dispositivo o permitem. Foucault (1998) sempre nos lembra disso "lá onde há poder há resistência".

Já, a fala de Sophia, com as mesmas considerações de dispositivo de Patrícia, quando ouvimos sua voz seja em off seja em no quadro, é para comentar pequenas ocorrências do diaa-dia, relatar suas memórias ou para fazer formulações do "eu" baseadas em preocupações existenciais dela em relação a sua escolha como antropóloga, às angústias em relação ao "eu" de Patrícia e, também, em relação às lembranças sobre os problemas de saúde do joelho que sofre desde pequena. O dispositivo e a prática experimental do jogo de subjetividades utilizadas no filme, escancara essas inquietações de Sophia. Uma constatação disso é dada em dois momentos expressivos do filme: o primeiro, íntimo e pessoal de intersubjetividade na quarta parte do filme, permite um jogo relacional de espelhos entre Sophia e Patrícia. É como se a narrativa das experiências de uma ecoasse na outra e viceversa. Não é por acaso que as memórias de ambas focam na estética corporal, a infância e na saúde delas. A segunda constatação é dada pelo papel dominante de Patrícia no exercício experimental: dela partem, as normas ou protocolos do dispositivo que serão utilizados nos procedimentos cinematográficos para colocar em cena os jogos intersubjetivos entre elas. É ela que comanda os desdobramentos fílmicos. Além de existir uma admiração de Sophia pelo trabalho de Patrícia, sempre estão presentes em suas memórias, o resultado da pressão da memória coletiva de ser mulher na cultura ocidental.

Para terminar, diríamos que Teko Haxy é um filme documentário ensaístico híbrido que se 
remete, de um lado, à coexistência de elementos de autoetnografia, de diário, de autobiografia construída a duas personagens, portanto plural. Sophia e Patrícia afetam e são afetadas pelo próprio fazer fílmico e pelas relações que este fazer implica. Com essas relações, o espectador tem acesso ao compartilhamento de um processo vivido pelas cineastas e pelos personagens envolvidos e ainda experimenta, junto com os atores sociais do dispositivo, alguns dos seus processos de individuação. De outro lado, e híbrido também, porque quando falamos em autoetnografia ou filmes autobiográficos performáticos, logo pensamos que são filmes em primeira pessoa que "falam", do ponto de vista articulado do cineasta, que, por sua vez, assume prontamente sua posição subjetiva. No entanto, gostaríamos aqui de fazer uma pequena reflexão: a estrutura gramatical de primeira pessoa pode ser no singular e no plural. Isto é, o "eu" não existe sozinho, ele existe inserido em um "nós" plural baseado no coletivo. Nosso argumento é que o ser é sempre "estar com", que o "eu" não é anterior a "nós", que a existência é essencialmente coexistência. Nesse sentido, ficamos um pouco convencido o que Jean-Luc Nancy (2000) nos diz sobre o ser singular plural, em que o indivíduo "eu" não existe sozinho, mas sempre "com" outro, ou seja, ser "um" nunca é singular, mas sempre implica "outro". Apesar de acreditarmos que o "eu" expressa nossa individualidade, ele também expressa nossa comunhão, nossa pluralidade, nossa inter-relação com um grupo, com uma sociedade, no nosso caso com uma determinada comunidade, pois nas narrativas de Patrícia, o “eu” dela é, o tempo todo, o "nós” do povo Mbyá.

\section{Referências bibliográficas}

AUMONT, Jacques et al. A estética do filme. Campinas, Papirus, 1995.

BELLOUR, Raymond. Entre-imagens: foto, cinema, vídeo. Campinas: Papirus, 1997.

CAIUBY, Novaes S, HARTMANN, Thekla O. Jogo de espelhos: imagens da representação de si através dos outros. Universidade de São Paulo, São Paulo, 1990.

CASTRO, Eduardo Viveiros de. "Transformação" na antropologia, transformação da "antropologia". Mana, Rio de Janeiro, v. 18, n. 1, p. 151-171, Apr. 2012. Available from $<$ http://www.scielo.br/scielo.php?script $=$ sci_ arttext\&pid=S0104-93132012000100006\&lng=e $\mathrm{n} \& \mathrm{nrm}=\mathrm{iso}>$. access on 05 May 2020.

CLIFFORD, James. Sobre a autoridade etnográfica. In: A experiência etnográfica: antropologia e literatura no século XX. Rio de Janeiro: Editora UFRJ, 1998.

CLIFFORD, James e MARCUS, E. George. Writing Culture: The Poetics and Politics of Ethnography. University of California Press.1986

COMOLLI, Jean-Louis. Ver e Poder - A inocência perdida: o cinema, televisão, ficção, documentário. Belo Horizonte: Editora UFMG, 2008.

FOUCAULT, Michel. Vigiar e Punir: nascimento da prisão. Trad. Lígia M. Ponde Vassalo. Petrópolis: Vozes, 1987.

História da sexualidade I: a vontade de saber. Rio de Janeiro: Edições Graal, 1998.

FRANCE, de Claudine. Cinema e antropologia. Campinas, SP, Editora da Unicamp, 1998

\section{Do filme antropológico à} antropologia fílmica, Campinas: Editora da Unicamp, 2000.

FRANCE, Xavier de: Eléments de scénographie du cinéma. Nanterre, Université de Paris X, Formation de Recherches Cinématographiques, collection Cinéma et Sciences Humaines, $\mathrm{n}^{\circ}$ 8, 1989 [1982].

GABARA, R. From Split to Screened Selves: 
French and Francophone Autobiography in The Third Person. Stanford, CA: Stanford University Press, 2006.

GALLOIS, Dominique e CARELLI, Vincent. "Vídeo e diálogo cultural: experiência do projeto Vídeo nas Aldeias". In: Horizontes Antropológicos. Porto Alegre, ano 1, número 2, julho/setembro 1995.

GAUDREAULT, André e JOST, François. A narrativa cinematográfica. Brasília: Editora da UnB, 2009.

HUSCH, Luc de. "Intruduction à la ritologie genérale". In: Edgar Morin et Massimo PiattelliPalmarini (eds.), Lunité de l'homme, invariants biologiques et universaux culturels. Paris, Éditions du Seuil, 1974.

LANE, Jim. The Autobiographical Documentary in America. Madison, WI: University of Wisconsin Press, 2002.

LINS, Consuelo. O filme-dispositivo no documentário brasileiro contemporâneo. In Vários Autores. Sobre Fazer Documentário. São Paulo: Itaú Cultural, 2007.

NANCY, Jean-Luc. Sendo plural singular. Stanford, CA:Stanford University Press, 2000.

NICHOLS, Bill. Introdução ao documentário. Campinas: Papirus Editora, 2007.

The Voice of Documentary. In: ROSENTHAL, Allan. New Challenges for Documentary. Berkeley and Los Angeles: University of California Press, 1988.

PARENTE, ANDRE. Narrativa $e$ Modernidade, Os cinemas não-narrativos do pósguerra. Papirus Editora, 1994.

PINHEIRO, Sophia. "A imagem como arma: a trajetória da cineasta indígena patrícia ferreira pará yxapy". Dissertação (Mestrado)
- Universidade Federal de Goiás, Faculdade de Ciências Sociais (FCS), Programa de PósGraduação em Antropologia Social, Goiânia, 2017.

PLANTINGA, Carl. Moving Pictures and the Rhetoric of Nonfiction Film. In: BORDWELL, David e CARROLL, Noël. Post Theory Reconstructing Film Studies. Madison: The university of Winsconsin Press, 1996.

Rhetoric and Representation in Nonfiction Film. New York: Cambridge University Press, 1997.

REED-DANAHAY, Deborah E. Auto/ Ethnography: Rewriting the Self and the Social. New York: Berg, 1997. xiv + 277 pp.

RENOV, Michael. The Subject of Documentary. Minneapolis, MN: University of Minnesota Press, 2004.

RICOEUR, Paul. Entre tempo e narrativa: concordância/discordância. Kriterion, Belo Horizonte, v. 53, n. 125, p. 299-310, June 2012

Available from <http://www.scielo.br/scielo. php?script $=$ sci_arttext\&pid $=$ S0100-512X201200 $0100015 \& \operatorname{lng}=$ en $\& n r m=$ iso $>$. access on 29 May 2020 .

REYNA, Carlos P. Reyna. Antropologia do Cinema: as narrativas cinematográficas na pesquisa Revista Teoria e Cultura da UFJF, v. 12 n. 2 jul. a dez, pp. 37-52. 2017 ISSN 2318-101x (on-line). Disponível e, < https://periodicos. ufjf.br/index.php/TeoriaeCultura/article/ view/12376> acesso em 07 mai. 2020. https:// doi.org/10.34019/2318-101X.2017.v12.12376

RUIZ, Coraci B. Documentario-dispositivo e video-cartas: aproximações. 2009. 117 p. Dissertação (mestrado) - Universidade Estadual de Campinas, Instituto de Artes, Campinas, SP. Disponível em: <http://www.repositorio. unicamp.br/handle/REPOSIP/284016>. Acesso em 19/05/2020. 
RUSSEL, Catherine. Autoethnography: Journeys of the Self, In Experimental ethnography: the work of film in the age of video. Londres: Duke University Press, 1999.

SHAPIRO, Judith. From Tupã to the Land without Evil: the christianization of Tupi-guarani cosmology. American Ethnologist, v. 14, n. 1, p. 126-139, fev. 1987.

TRUFFAUT, François. El cine según Hitchcock, Madrid, ed. Alianza, 1998.

TEKO HAXY- SER IMPERFEITA. Verberenas. Edição 04. Disponível em: https:// www.verberenas.com/article/teko-haxy/. Access on 3 June 2020.

WAGNER, Roy. A invenção da cultura. São Paulo,. Cosac Naify, 2010

VERSIANI, Daniela. B. Autoetnografias: conceitos alternativos em construção. Rio de Janeiro: 7Letras, 2005.

\section{Filmografia}

33. Dir.Kiko Goifman, 2003, 1h 14min / Documentário

Crônica de um verão. Dir. Jean Rouch e Edgard Morin , 1960, Documentário em cores/90'.

Passaporte Húngaro. Dir. Sandra Kogut, 2002. Documentário - 1h $14 \mathrm{~m}$

Les glaneurs et la glaneuse... deux ans après. Dire. Agnès Varda, 2002. Documentário - 1h 3m

Le joli mai. Dir. Chris Marker, 1963. Documentário - 2h $45 \mathrm{~m}$

Nannok. Dir. Robert Flaherty, 1922. Documentário/Mudo - 1h 23m

Navajo Film Themselves. Dir. Sol Worth e John Adair. 1966. Série de sete curtas documentários.

Sherman's March. Dir. Ross McElwee, 1987. Documentário/Independente - $2 \mathrm{~h} 37 \mathrm{~m}$ 